\title{
EXTERNAL COMPARISON SATELLITE POSITIONS OBTAINED BY THE NETWORK OF PASSIVE CORRELATION RANGING OF GEOSTATIONARY TELECOMMUNICATION SATELLITES
}

\author{
F.Bushuev ${ }^{1}$, M.Kaliuzhnyi ${ }^{1}$, O.Mazhaev ${ }^{1}$, O.Shulga ${ }^{1}$, L.Shakun ${ }^{2}$, V.Bezrukovs ${ }^{3}$, \\ O.Reznichenko ${ }^{4}$, S.Moskalenko ${ }^{5}$, Ye.Malynovskyi ${ }^{6}$ \\ ${ }^{1}$ Research Institute "Mykolaiv Astronomical Observatory" (RI "MAO”), Mykolaiv, \\ Ukraine,dir@mao.nikolaev.ua \\ ${ }^{2}$ Research Institute "Astronomical Observatory" of the Mechnikov Odesa National \\ University, Odesa, Ukraine, astronomical_observatory@onu.edu.ua \\ ${ }^{3}$ Ventspils University College, Ventspils, Latvia,virac@venta.lv \\ ${ }^{4}$ Institute of Radio Astronomy of the NASU, Kharkiv, Ukraine, rai@ri.kharkov.ua \\ ${ }^{5}$ Western Center of Radio Engineering Surveillance, Mukacheve, Ukraine, ckako@i.ua \\ ${ }^{6}$ Rivne Minor Academy of Science of School Age Youth, Rivne, Ukraine, \\ man.rivne@ukr.net
}

\begin{abstract}
Network of passive correlation ranging contains of five stations located in Ukraine and Latvia. It has been created at the initiative of the RI "Mykolaiv Astronomical Observatory" to have independent means to track the future Ukrainian geostationary satellite "Lybid". Regular observations of the geostationary telecommunication satellite "Eutelsat-13B" has being carried out by the network since February 2015. A catalog of daily orbital elements of the tracked satellite has been created using the network observations. The analytical model SGP4/SDP4 of satellite motion and a numerical model of integration of equations of satellite motion are used to determine the orbital elements. The numerical model takes into account the gravitational attraction of the Sun and Moon, and nonspherical Earth. Software of the orbital elements determinations has been developed by the RI "Astronomical Observatory" of the Mechnikov Odesa National University.

Satellite positions calculated using orbital elements from the catalog were compared with ones obtained using the NORAD space-track.org site and optical observations performed by the Ukrainian Network of Optical Stations. The satellite position comparisons were carried out only for time intervals of unperturbed motion of the satellite. The free motion time intervals were determined using the algorithm that had been tested using satellite owner data about the moments of satellite maneuvers. Herewith values of right ascension and declination were compared. Regular (mean) and random (standard deviation) values of the residuals are given in the report.
\end{abstract}

Keywords: geostationary satellite, passive correlation ranging, orbital elements.
АБСТРАКТ. До складу мережі пасивного кореляційного дистанціювання входять п'ять станцій розташованих в Україні і в Латвії. Мережа була створена за ініціативою НДІ «Миколаївська астрономічна обсерваторія» як незалежний засіб супроводу майбутнього українського геостаціонарного супутника «Либідь». Регулярні спостереження геостаціонарного телекомунікаційного супутника «Eutelsat-13В» проводяться мережею з лютого 2015 року. За результатами спостережень створено каталог щодобових значень елементів орбіти супроводжуваного супутника. Елементи орбіти визначаються 3 використанням аналітичної моделі SGP4/SDP4 руху супутника та чисельної моделі інтегрування рівнянь руху супутника. Чисельна модель враховує гравітаційне тяжіння Сонця і Місяця, а також несферичної Землі. Програмне забезпечення для визначення елементів орбіти було розроблено в НДІ «Астрономічна обсерваторія» Одеського національного університету імені I.І.Мечникова.

Положення супутника, обчислені з використанням елементів орбіти 3 каталогу, порівнювалися 3 положеннями, обчисленими 3 використанням елементів орбіти 3 сайту NORAD space-track.org, а також 3 положеннями, отриманими в результаті оптичних спостережень, виконаних Українською мережею оптичних станцій. Порівняння положень супутника проводилися тільки для інтервалів часу незбуреного руху супутника. Інтервали часу незбуреного руху визначалися за алгоритмом, який був протестований з використанням даних про час виконання маневрів, отриманих від власника супутника. При цьому порівнювалися значення прямого сходження і схилення. В статті наводяться отримані регулярні (середнє) та випадкові 
(середньоквадратична похибка) значення різниці положень супутника.

Ключові слова: геостаціонарний супутник, пасивне супровід, елементи орбіти.

\section{Introduction}

The development of global satellite navigation and Internet, capable of providing device synchronization and data transfer, regardless of the distance between them, has led to the development of a cheap, fully passive, spatially distributed radio engineering system (network) to determine the position of geostationary satellites. The basic principle of the operation of such a network is the use of correlation analysis to calculate Time Difference Of Arrival (TDOA) of signals emitted by satellites and received by spatially separated network stations. Such a passive correlation ranging $(\mathrm{PaCoRa})$ system has been developed by the SES (Société Européenne des Satellites) in 20102013 and is considered by the European Space Agency (ESA) as a highly accurate alternative to conventional radar used two-way ranging method (ESA, 2018).

Network of passive correlation ranging (NetPCR) consisted of two stations has been created and tested by the RI "MAO" in August 2011. Since February 2015 the NetPCR carries out regular observations of the geostationary telecommunication satellite "Eutelsat-13B" first by four and then by five stations located in Ukraine and Latvia (Bushuev et al., 2016; Kaliuzhnyi et al., 2016). Singlemeasurement error (1 sigma) of the TDOA has been obtained and equal about \pm 8.7 ns for the all pairs of the stations. A catalog of daily satellite's orbital elements has been created using the analytical model SGP4/SDP4 of satellite motion and a numerical model of integration of equations of satellite motion. The internal error of coordinate determination of the tracked satellite has been obtained in a local orbital frame (Package, 2018) and it does not exceed $225 \mathrm{~m}$ that approximately equal to the error of the PaCoRa system (Bushuev et al., 2017). Means and standard deviations of the residuals of Eutelsat-13B Cartesian coordinates obtained by the NetPCR and Eutelsat (owner of the satellite) in the ITRF are also given in (Bushuev et al., 2017). The numerical model as more accurate has been used to calculate the coordinates. Herewith the maximum absolute value of the means was less than $900 \mathrm{~m}$ and the maximum standard deviation was $1280 \mathrm{~m}$. These values were obtained for the time when Eutelsat-13B orbit was undisturbed. The significant differences in coordinates may be due to the difference of satellite motion models used by Eutelsat and ourselves to calculate coordinates.

\section{Optical and radio observations comparison}

Optical observations of Eutelsat-13B have been performed in 2015 and 2016 by an automatic telescope KT50 which is a part of a complex of mobile telescopes (MOBITEL) of the RI "MAO" (Shulga, 2010). MOBITEL is also a part of the Ukrainian Network of Optical Stations (UMOS, 2018).
Right ascensions $\left(\alpha_{o}\right)$ and declinations $\left(\delta_{o}\right)$ measured by the telescope are compared with $\alpha_{r}$ and $\delta_{r}$ computed using daily orbital elements (the numerical model) from the NetPCR catalogue (Geostationary satellites, 2018). Herewith an inertial coordinate system was EME2000 (Earth's Mean Equator and Equinox) or J2000 and the space dynamic library OREKIT was used for astronomical computations (Orekit, 2018). Light-time correction was also taken into account to compute $\alpha_{r}$ and $\delta_{r}$ at the moment of optical measurements.

Totally the 24 different sets of $\alpha_{o}$ and $\delta_{o}$ were obtained but only 7 of them were taken into consideration. The reasons for the rejection of observations were as follows:

- Maneuver could take place during the day of the observation;

- Another satellite was observed in the same geostationary cell;

- Sample size of measured values of $\alpha_{o}$ and $\delta_{o}(N)$ was less than 4.

Satellite Cartesian coordinates in the ITRF were computed on the day ends (at 23:59 and 00:00) using orbit elements from the catalogue for three consecutive days: at a day of optical observations and at days before and after it. It is assumed that a maneuver may take place at the day if jumps of the coordinates on the ends were greater than $200 \mathrm{~m}$. The coordinate jump threshold $(200 \mathrm{~m})$ was determined using information about Eutelsat-13B maneuvers which was obtained from the satellite owner (Bushuev et al., 2017).

Another satellite (Eutelsat-13C or 13E instead of 13B) was observed if the residuals $(\Delta)$ between measured $\left(\alpha_{o}\right.$ and $\left.\delta_{o}\right)$ and calculated $\left(\alpha_{c}\right.$ and $\left.\delta_{c}\right)$ right ascensions and destinations were greater for Eutelsat-13B than for Eutelsat-13C or Eutelsat-13E. The NORAD data or TLE (Two Line Elements) orbital elements from the space-track.org site are used to calculate $\alpha_{c}$ and $\delta_{c}$.

Average values (Mean) and standard deviations (SD) of the optic-radio residuals $\left(\Delta_{\alpha o}=\alpha_{o}-\alpha_{r}\right.$ and $\left.\Delta_{\delta o}=\delta_{o}-\delta_{r}\right)$ are estimated for the 7 observations are shown in Table 1 in arc seconds.

Table 1: Means and standard deviations of the optic-radio residuals, arc seconds.

\begin{tabular}{|c|r|r|r|r|r|}
\hline Date & \multicolumn{1}{|c|}{$N$} & $\begin{array}{c}\text { Mean } \\
\text { of } \Delta_{\alpha o}\end{array}$ & $\begin{array}{c}\text { SD of } \\
\Delta_{\alpha o}\end{array}$ & $\begin{array}{c}\text { Mean } \\
\text { of } \Delta_{\delta o}\end{array}$ & $\begin{array}{c}\text { SD of } \\
\Delta_{\delta o}\end{array}$ \\
\hline 31.10 .15 & 12 & -10.0 & 2.3 & -10.2 & 0.5 \\
\hline 20.05 .16 & 18 & -12.5 & 5.7 & 4.1 & 0.9 \\
\hline 09.06 .16 & 15 & -15.1 & 3.0 & 0.7 & 0.7 \\
\hline 30.06 .16 & 12 & -16.4 & 1.5 & -2.8 & 0.7 \\
\hline 03.09 .16 & 9 & 36.5 & 2.3 & -7.2 & 0.3 \\
\hline 06.09 .16 & 8 & 36.7 & 1.8 & -6.7 & 0.4 \\
\hline 30.09 .16 & 12 & 26.5 & 2.5 & -11.1 & 0.2 \\
\hline
\end{tabular}

Table 1 shows that the mean (absolute value) and SD of $\Delta_{\alpha}$ are less than 37 " and 6", respectively. The corresponding values for $\Delta_{\delta}$ are equal 12" and 1". 
Table 2: Mean and SD intervals of the optic-radio and radio-NORAD residuals, arc seconds

\begin{tabular}{|l|c|c|c|c|}
\hline Residuals & Mean of $\Delta_{\alpha}$ & SD of $\Delta_{\alpha}$ & Mean of $\Delta_{\delta}$ & SD of $\Delta_{\delta}$ \\
\hline Optic-radio & $-15.4 \div 36.7$ & $1.5 \div 5.7$ & $-11.1 \div 4.1$ & $0.2 \div 0.9$ \\
\hline Radio-NORAD & $-11.4 \div-2.7$ & $2.4 \div 4.5$ & $-0.8 \div 0.4$ & $1.0 \div 4.9$ \\
\hline
\end{tabular}

\section{Comparison radio observations with NORAD data}

The values of $\alpha_{r}$ and $\delta_{r}$ are also compared with $\alpha_{c}$ and $\delta_{c}$ computed using NORAD data from the space-track.org site for the 7 days from Table 1 . The intervals of changing means and SD of the radio-NORAD residuals $\Delta_{a c}=\alpha_{r}-\alpha_{c}$ and $\Delta_{\delta c}=\delta_{r}-\delta_{c}$ are given in Table 2. The corresponding intervals for $\Delta_{\alpha o}$ and $\Delta_{\delta o}$ are also shown in the table for comparison.

Table 2 shows that the means of the residuals are less for the radio-NORAD residuals than the optic-radio ones. Herewith the standard deviations of the residuals are greater especially for $\delta$.

\section{Conclusion}

Eutelsat13-B positions obtained by the network of passive correlation ranging and gathered in the catalogue were compared with optical measurements and with the data from the space-track.org site (the NORAD data).

The comparisons were performed for 7 days in 2015 and 2016 when Eutelsat-13B positions were measured by the optical telescope KT-50 MOBITEL (RI "MAO") and the probability of satellite maneuver was minimum.

The means and standard deviations of $\alpha$ and $\delta$ residuals (optic-radio) are in the next intervals (arc seconds):

- Means of $\Delta \alpha:-15.4 " \div+36.7$ ", SD of $\Delta \alpha: 1.5 " \div 5.7 "$;

- Means of $\Delta \delta:-11.1 " \div+4.1$ ", SD of $\Delta \delta: 0.2 " \div 0.9 "$;

The regular components of the residuals (means) between the NetPCR and NORAD $\alpha$ and $\delta$ were less than the similar values for the optic and NetPCR measurements. Herewith the random components (SD) were greater especially for $\delta$.

The following is proposed to improve the NetPCR accuracy:

- Eliminate hardware errors (including inaccuracy of antennae phase centers positions);
- Taking into account tropospheric delays and lighttime corrections during orbital elements computations using the numerical model of satellite motion.

\section{References}

Bushuev F., Kaliuzhnyi M., Sybiryakova Ye. et al.: 2016, Latvian Journal of Physics and Technical Sciences, 53, No. 5, 5.

Bushuev F. Kaliuzhnyi V., Shulga O. et al.: 2017, in Proceedings of the 9th IAASS Conference Session 11: Space Traffic Control - I, Toulouse (France), 18-20 October 2017, 213.

ESA. BUSINESS APPLICATIONS. ARTES. PASSIVE CORRELATION RANGING (PACORA), [online]. Available at: https://artes.esa.int/projects/passivecorrelation-ranging-pacora [Accessed 10 October 2018].

Geostationary satellites. Radio interferometric network for tracking of geostationary telecommunication satellites, [online]. Available at: http://www.nao.nikolaev.ua/ index.php?catalog_id=459 [Accessed 10 October 2018].

Kaliuzhnyi M., Bushuev F., Shulga O. et al.: 2016, Odessa astronomical publications, 29, 203.

Orekit. An accurate and efficient core layer for space flight dynamics applications, [online]. Available at: http://orekit.org/ [Accessed 10 October 2018]

Package org.orekit.frames Class LocalOrbitalFrame, [online]. Available at: https://www.orekit.org/static/ apidocs/org/orekit/frames/LocalOrbitalFrame.html [Accessed 10 October 2018].

Shulga O., Kozyryev Y., Sybiryakova Y..: 2010, Proc. of Gaia follow-up network for Solar system objects workshop held at IMCCE-Paris observatory, November 29 - December 1, 2010, France, 97.

UMOS. Ukraine Network of Optical Stations, [online]. Available at: http://umos.mao.kiev.ua/eng/ [Accessed 10 October 2018]. 